\title{
Aile Katılımında Alternatif Arayışları: İzmit Roman Aileleri Örneği ${ }^{1}$
}

\author{
Dr. Öğr. Üyesi Tuğba KONAKLI* \\ Kocaeli Üniversitesi, Eğitim Fakültesi, Umuttepe Yerleşkesi, İzmit / Kocaeli / Türkiye, \\ tdegirmenci@kocaeli.edu.tr, ORCID: 0000-0003-4745-1805 \\ Doç. Dr. Şöheyda GÖKTÜRK \\ Kocaeli Üniversitesi, Eğitim Fakültesi, Umuttepe Yerleşkesi, İzmit / Kocaeli / Türkiye, \\ doyuran@kocaeli.edu.tr, ORCID: 0000-0002-4906-2654
}

\section{Öz}

$\mathrm{Bu}$ araştırmada Roman ailelerin temel eğitim kapsamındaki çocuklarının eğitim süreçlerine nasıl katılabileceklerinin incelenmesi ve bu katılımın etkin olarak işletilebilmesi için okul yönetiminden, öğretmenlerden, velilerden ve diğer okul paydaşlarından beklentilerinin ortaya çıkarılması, otantik Roman kültürüne uyumlu ortaklaşa bir aile katılım anlayışının geliştirilmesi amaçlanmıştır. Nitel desende tasarlanan bu araştırmada Roman ailelerden elde edilen veriler odak grup görüşme tekniği ile toplanmıştır. Araştırmada amaçlı örnekleme yöntemlerinden ölçüt örnekleme yöntemi kullanılmıştır. Çalışma grubu, Kocaeli’nin İzmit ilçesinde Dezavantajlı Kişilerin Sosyal Entegrasyonu ile İstihdam Edilebilirliklerinin Geliştirilmesi Hibe Programı kapsamında

\footnotetext{
${ }^{1}$ 11-13 Mayıs 2017 tarihinde 12. Uluslararası Eğitim Yönetimi Kongresi’nde sözlü bildiri olarak sunulmuştur.

* Sorumlu Yazar. Tel: +902623032426

(C) 2018 Kalem Eğitim ve Sağlık Hizmetleri Vakfı. Bütün Hakları Saklıdır. 
başlatılan, "Roman Kadınların İkinci Baharı" projesine katılım gösteren veliler arasından oluşturulmuştur. Bu bağlamda çalışma grubuna çocukları temel eğitim kapsamında olan 13 katılımcı dâhil edilmiştir. Elde edilen verilerin analizinde içerik analizi yöntemi kullanılmıştır. Araştırma bulguları, Roman velilerin aile katılımını ev temelli ve okul temelli olarak gösterdiklerini ortaya koymuştur. Roman velilerin okula kat1lım konusunda yaşadıkları en önemli zorluk "Ayrımcılık” olarak nitelendirilmiştir. Araştırmanın çalışma grubundaki velilerin çocukların eğitim öğretim süreçlerine önem verdiklerini ifade ettikleri, okuldan ve öğretmenlerden ilgi, destek ve anlayış bekledikleri böylece okula katılım konusunda daha istekli olabilecekleri sonucuna ulaşılmıştır. Araştırma bulgularından yola çıkılarak Roman ailelerin aile katılımının teşvik edilmesi amacıyla okullar tarafindan veli ve öğrencilerin bütünleştirildiği çeşitli sanatsal, kültürel ve sportif etkinlikler düzenlenebilir. Bu yolla ayrımcılığa yönelik tutumların azalması beklenebilir. Ayrıca okulların ve ailelerin birbirlerinden beklentilerine yönelik konuşmaların gerçekleşeceği platformların oluşturulması, ailelerin kendilerine özgü yapılarının okul yönetimi ve öğretmenler tarafından tanınmasına olanak sağlayabilir.

Anahtar Kelimeler: Roman aileler; Temel eğitim; Aile katılımı.

\title{
Alternatives to Family Participation: The Case of Izmit Roman Families
}

\begin{abstract}
In this study, it was aimed to investigate how Gypsy families can participate in the education process of their children in the scope of primary education, to reveal the expectations from the school management, teachers, parents and the other school stakeholders for the management of these participations effectively and to develop a collective family participation understanding compatible with authentic Gypsy culture. In this study, designed in qualitative model, the data obtained from the Gypsy families were collected using the focus group interview method. Out of the purposive sampling methods, criterion sampling method was used. The study group was formed from the parents who participated in the project "Second Spring of Gypsy Women" started within the scope of the Grant Scheme for the Social Integration and Improvement of Employment Opportunities of Disadvantaged People in İzmit district of Kocaeli. In this context, 13 participants whose children were in the scope of primary education were included in the study group. In the
\end{abstract}


analysis of the obtained data, the content analysis method was used. The findings of the study revealed that Gypsy parents showed family participation as home-based and school-based. The most important difficulty the Gypsy families experienced in school participation was specified as "Discrimination". It was concluded that the parents in the study group of the research attached importance to education and training process of their children, they expected attention, support and understanding from the school management and teachers so that they could be more willing to school participation. Based on the findings of the study, various artistic, cultural and sportive activities, where parents and students are integrated, can be organized by schools to promote the family participation of Gypsy families. In this way, discriminatory attitudes can be expected to decrease. In addition, creation of platforms where families and schools express their expectations from each other can enable school management and teachers to recognize distinctive structures of the families.

Keywords: Gypsy families; Primary education; Family participation.

\section{Extended Summary}

\section{Purpose}

It was aimed to investigate how Gypsy families can participate in education processes of their children in the scope of primary education, to reveal the expectations from the school management, teachers, parents and the other school stakeholders for the management of these participations effectively and to develop a collective family participation understanding compatible with authentic Gypsy culture.

\section{Method}

Based on the purpose of this study designed in qualitative model, the data obtained from the Gypsy families were collected using the focus group interview method. Out of the purposive sampling methods, criterion sampling method was used. A study group in which the regions where Gypsy families lived extensively in İzmit district of Kocaeli and the opinions of the parents who were volunteer to participate in the study and have different employment and education status with children receiving primary education in these regions were reflected was created. The study group was formed from the parents who participated in the project "Second Spring of Gypsy Women" started within the scope of the Grant Scheme for the Social Integration and Improvement of Employment Opportunities for Disadvantaged People in İzmit district 
of Kocaeli. In this context, 13 participants whose children were in the scope of primary education were included in the study group. In the study, a semistructured interview form compatible with the general purposes was used. In the interviews, in-depth information was collected because of the facts that the interviewers were free to express their opinions, the interviews were not limited to a certain period and the questions which were not understood clearly were re-explained. In addition, the researcher used note taking and using voice recorder methods together in the interviews. In the analysis of the obtained data, the content analysis method was used.

\section{Results}

According to the obtained data, the participation styles of the parents in the education and training process of their children were gathered under school-based and home-based categories. The codes parents specified under school-based participation styles are as follows: going to the school, meeting with the principal and the teacher, speaking to the teacher on the phone, participation in school meetings, participation in school activities, going to the school and speaking to their children's friends. Home-based participation styles are as follows: speaking to their children about school, encouraging their children to participate in school activities, family elders' following up their children, meeting school expenses, counseling, rewarding, doing homework/activities, preparing their children for school, doing whatever their children want. According to the obtained data, the difficulties parents had in meeting the expectations for school participation were gathered under "Discrimination" and "School expenses" categories. The expectations of parents for school participation were gathered under "expectations from school" category. The codes specified under this category are as follows: financial aid, being informed, attention and support, different circle of friends and project. The opinions of parents about the questions on this topic were seen to be concentrated on attention and support code and project code in general.

\section{Discussion}

The findings of the study revealed that Gypsy parents showed family participation as home-based and school-based and home-based participation was performed as counseling, speaking to their children about school and doing whatever their children want. It can be considered as a code specific to Gypsy families that parents do whatever their children want and support them. As a matter of fact, it was stated in some research findings that Gypsy families 
have a more protective attitude towards their children as well (McCray, 2006).

The most important difficulty the Gypsy families experienced in school participation was specified as "Discrimination". Gypsy parents stated that their children and they were labeled by the school director, teachers, the other students and their parents as they were Gypsies. This situation can cause Gypsy children to drop out of school and be absent from school. Another reason that prevents school participation of parents is the difficulties to meet the school expenses. The findings obtained in the study overlap with the limited number of research findings on Gypsies (Diktaş, Deniz and Balcıoğlu, 2016; Genç, Taylan and Barış, 2015; Kabaklı, 2013).

In the study, the participants were asked questions about whether there were people who supported the children's education and training process and could be a role model for them. It was stated that only parents and some family elders were supportive in this respect. It was stated that especially boys take other children in their surrounding as an example and drop out of school. This situation can cause children to be reluctant to education (Diktaş, Deniz and Balc1oğlu, 2016; Kabaklı, 2013).

\section{Conclusion}

In the study, it was determined that parents take their children's desire not to go to school naturally to do whatever their children want and protect them from discriminatory behaviors. Although the parents in the study group stated that they attached importance to the education and training process of their children, it was concluded that they expected attention, support and understanding from the school management and the teachers and in this way, they could be more willing to school participation. This finding shows that parents have expectations about life. Unlike some studies conducted until today (Uzun and Bütün, 2015), it was seen that parents believed that they could reach the goals they set for themselves and their children through education. Parents also expect schools to develop projects that will enable their children to be in different environments from the social environment they are in (Kabakl1, 2013). They state that these projects will encourage them and their children for school participation. Indeed, presentation of projects about family participation by schools trying to understand various features of sub-cultures may increase participation (Estyn, 2009; Lopez, 2001).

Based on the findings of the study, various artistic, cultural and sportive 
activities, where parents and students are integrated, can be organized by schools to promote the family participation of Gypsy families. In this way, discriminatory attitudes can be expected to decrease. In addition, creation of platforms where families and schools express their expectations from each other can enable school management and teachers to recognize distinctive structures of the families. It can be suggested to share the objectives of school with parents explicitly, to determine the roles of parents in the accomplishment of these objectives and to share the opinions about how to provide potential support of parents in this process. In the following researches to be conducted on this issue, presentation of family participation styles of different sub-cultures can be taken into consideration.

\section{Giriş}

Aile katılımı, okullardaki eğitim öğretim süreçlerinin etkiliğini sağlama, bu süreçleri destekleme ve uygulamaları başarıya ulaştırmada birincil değişkenlerden biridir. Okul ile ev arasındaki koordinasyonun sağlanması olarak nitelendirilen aile katılımı, ailelerin, okulun akademik ve sosyal amaçlarını gerçekleştirmek için öğrenme etkinliklerine, okuldaki planlamaya ve yönetime etkin olarak katılmasıdır (Çakmak, 2010; Keçeli-Kayısı11, 2008). Alanyazında üç tür aile katılım formundan bahsedilmektedir. Bunlar okul dışında velinin çocuğuyla evde sağladığı etkileşim olan ev temelli katılım, okul tarafindan düzenlenen etkinliklere katılma gibi okul içi etkinlikleri kapsayan okul temelli katılım, öğretmenle görüşmek, sorunlarla ilgili okul personeliyle konuşmak, öğretmenin düzenlediği toplantılara katılmak şeklinde gerçekleştirilen işbirliği temelli katılımdır (Hoover-Dempsey ve ark., 2005; Lee ve Bowen, 2006; Stewart, 2008).

Aile katılımı öğrencilerin akademik başarısını arttırmakta (Dearing, Kreider, Simpkins ve Weiss, 2006; Hayakawa, Englund, Warner-Richter ve Reynolds, 2013; Jeynes, 2007) ve okul terk oranlarının azalarak okulu bitirme oranlarının artmasını sağlamaktadır. Ayrıca aile katılımının ebeveynlik davranışlarını olumlu yönde geliştirdiği, çocukluk dönemi davranış sorunlarının azalmasını sağladığı saptanmıştır (Brotman ve ark., 2011; Kratochwill, McDonald, Levin, Scalia ve Coover, 2009). Dolayısıyla aile katılımı sadece öğrencinin akademik başarısını arttırmakla kalmayıp aynı zamanda öğrencinin okula yönelik olumlu tutum geliştirmesine, öğrenmeye yönelik motivasyonunun artmasını da sağlamaktadır.

Araştırma bulguları ailelerin okulla ilgili etkinliklere katılımlarının 
yetersiz olduğunu göstermektedir (Durmuş, 2016; Kıliç, 2009; Erdoğan ve Demirkasımoğlu, 2010). Okulların aile katılımını kendi belirlediği yer, zaman ve biçimde gerçekleştirmesi farklı çalışma koşulları, eğitim ve sosyo ekonomik düzeylerde olan ailelerin katılımını olumsuz etkileye-bilmektedir. Ailelerin farklı çalışma koşulları, farklı sosyo ekonomik statülerde olmalarının yanısıra eğitime ilişkin beklenti ve görüşlerinin farklılaşması da okulların belirlemiş olduğu standart aile katılım biçimle-rinden uzak olmalarına neden olabilmektedir.

Aile katılımına yönelik Türkiye'de farklı eğitim kademelerinde yapılan araştırmalar, konunun gerekliliğinin aileler, öğretmenler ve yöneticiler tarafindan yeterince benimsenmediği, dolayısıyla aile katılımının beklenen düzeye ulaşamadığını göstermektedir (Erdoğan ve Demirkasımoğlu, 2010; Keçeli-Kayısılı, 2008; Topçu, 2013). Öğretmenlerin çoğunluğu veliyi öğrencinin genel durumu (devamsızlık, ders başarısı, not, disiplin sorunları vb.) için okula çağırmaktadır. Veliler ise acil bir durum olmadığı takdirde öğretmenlerin kendilerini aramamalarını normal karşılamaktadır. Öğretmen, yönetici ve velilerin aile katılımı konusunda istekli olmalarına rağmen katılımın nasıl gerçekleştirileceğine yönelik bilgi sahibi olmadıklarını ortaya koymaktadır (Çağdaş, Özel ve Konca, 2016; Durmuş, 2016; K1lıç, 2009; Kıranşal, 2007; Ünüvar, 2010; Vural ve Kocabaş, 2016). Aile katılımı çoğunlukla veli toplantıları ile sınırlandırılmaktadır. Oysa ailelerin okuldaki sosyal etkinliklere katılmaları, ev temelli, okul temelli olarak katılım gösterebilecekleri ve okulla düzenli iletişim ağı kurmalarını sağlayan bir sistem aile katılımını amacına ulaştırabilir (Abbak, 2008; Çalık, 2007; Özgan ve Aydın, 2010). Aile katılımına yönelik Millî Eğitim Bakanlığı'nın çalışmalarına rağmen beklenen seviyeye ulaşılamama nedenleri çeşitlilik göstermektedir. Katılımın gerekliliğine inanmama, iletişim kurma güçlüğü, ailelerin eğitim, sosyo ekonomik düzeyleri öncelikli olan aile katılım engelleri arasındadır (Çınkır ve Nayır, 2016; Kotaman, 2008; Saban ve Şeker, 2010; Salıc1-Ahioğlu, 2006).

Bugüne kadar yapılan araştırmalar, ailelerin katılıma yönelik görüşlerini, öğretmen ve yöneticilerin ise katılım beklentilerini ortaya koymakta, Millî Eğitim Bakanlı̆̆̆'nın çalışmaları ise katılımının gerekliliğini vurgulamaktadır. Dolayısıyla bu araştırmaların aile katılımına yönelik "Ne düzeyde?" sorusuna yanıt aradığı görülmektedir. Bu durum geleneksel aile katılım yöntemlerinin sorgulanması gerekliliğini ortaya koymaktadır. Okullar bulundukları koşullar (Öğretmen, öğrenci sayısı, okulun fiziksel imkânları, öğretmen 
ve yönetici niteliği gibi) ve beklentileri doğrultusunda aile katılımına yönelik standartlar, şablonlar oluşturmaktadır. Ancak bu derece standart koşullar her ailenin katılıma yeterli seviyede ilgi göstermesine engel olabilir.

Ailelerin kendilerine özgü özellikleri aile katılımlarını ve katılım konusundaki anlayışları farklılaşmaktadır. Düşük sosyo-ekonomik düzeydeki ailelerin, çocuklarının eğitim sürecine katılmak yerine ailelerinin ihtiyaçlarını karşılamayı tercih ettikleri öne sürülmektedir. Bu aileler aile katılımı konusunda finansal yetersizlikle birlikte stres yaşamaktadırlar. Ayrıca eğitim düzeyinin düşük olması eğitim öğretim yaşantılarının sınırlılığı nedeniyle kendilerini bu sürece katılım konusunda yetersiz görebilmektedirler (Kaplan, Liu ve Kaplan, 2001; Waanders, Mendez ve Downer, 2007). Buna rağmen araştırmalar, sınırlı kaynaklara sahip olan ailelerin de çocuklarının akademik süreçlerine katılım gösterme konusunda destekleyici olabileceklerini göstermektedir (Grolnick, Friendly ve Bellas, 2009; McKay ve Stone, 2000).

Romanlar, çeşitli kültürel profillerden oluşan grupların bir mozaiği olmakla birlikte birçok ülkede en dezavantajlı etnik gruplar arasındadır (Liegeois, 1998). Bu grup, Yunanistan'la 1923 yılında yapılan Lozan antlaşmasıyla Türkiye'ye gelenlerden oluşmaktadır. Ege, Trakya ve Karadeniz bölgelerine yerleştirilmişlerdir ve günümüzde çoğunlukla, İzmir, Aydın, Manisa, Çanakkale, Balıkesir, Bursa, Kocaeli, İstanbul, Tekirdağ, Kırklareli Zonguldak, Bartın ve Samsun illerinde yaşamaktadırlar (Kolukırık, 2008). Romanların kesin olarak nüfusları bilinmemekle birlikte dünyada ve Türkiye'de önemli bir nüfus oranına sahip olduğu belirtilmektedir. Ağırlıklı olarak Roman nüfusuna sahip olan ülkeler arasında Bulgaristan \%10.33'lük bir oranla ilk sirada yer almakta, Slovakya (\%9.17), Romanya (\%8.32) ve Macaristan'ın (\%7.05) ilk siralarda gelmektedir. Türkiye'de bu oran \%3.83'tür ve tahmini Roman nüfusu 2.750.000 olarak verilmektedir. Romanların sıklıkla yaşadıkları sorun alanları eğitim, sağlık, istihdam ve barınmadır (Ocakl1, 2013). Türkiye'de Roman öğrenciler arasında okula devamsızlığın büyük bir sorun olduğu bilinmektedir. Okula devamsızlık düşük akademik başarı, okula uyum ve okul bırakma gibi sorunları beraberinde getirmektedir. Bu durum Romanların eğitim sisteminin dışında kalmasına ya da eğitim sürecinde başarısız olmasına neden olmaktadır (Akkan, Deniz ve Ertan, 2011; Uzun ve Bütün, 2015).

Okul çağındaki Roman çocuklar alt eğitim kademelerinde kalmakta ve düşük başarı göstermektedir (Bhopal, 2004; Liegois, 1998; Warrington, 2007). Nitekim İngiltere, İskoçya ve Kuzey İrlanda'da Romanlarla ilgili 
yapılan araştırmalar, eğitime katılımın düşüklüğü, düşük başarı, disiplin sorunları, taciz ve zorbalık, verilen işi devam ettirmeme, yetersiz destek, okul terki, devamsızlık ve Roman öğrencilerin eğitim süreçlerindeki özel gereksinimlerine yöneliktir (Bhopal, 2004; Derrington, 2005; Derrington ve Kendall, 2003; Lloyd ve Stead, 2001; Reynolds, McCartan ve Knipe 2003). Öğrencilerin yaşadıkları çevre ve ev ortamları ile okul yaşantıları arasındaki uyuşmazlık akademik başarısızlıklarının temel nedenleri arasındadır (Forray, 2003; Salinas, 2007). Bazı Roman ailelere göre eğitim, basit bir şekilde okuma ve yazma bilmek anlamına gelmektedir. Buna göre ilkokula gitmenin çocuklara pratikte bir fayda sağlamayacağını bunun aksine evde ve çevreden edindikleri becerilerin daha önemli olduğu görüşündedirler (Myers, McGhee ve Bhopal, 2010). Aileler okulları, çocuklarının eğitim göreceği en iyi seçenek olarak görmemekte ve okullardaki eğitimin, müfredatın kendi gerçek yaşamlarından kültürlerinden uzak olduğunu düşünmektedirler (Myers ve Bhopal, 2009).

Türkiye'deki Romanlar diğer Avrupa ülkelerinde yaşayan Romanlarla benzer sosyo-ekonomik zorluklarla karşı karşıya kalmaktadır. Yoksulluk ve işsizlik oranları, okula devam ve bitirme oranlarının azlığı meslek edinmeyi olanaksızlaştırmakta veya edinilen mesleki becerinin zayıflığına sebep olmaktadır. Bu durum beraberinde olumsuz barınma koşulları ve kötü sağlık koşullarını getirmektedir. Tüm bunlar Romanların yaşamdan beklentilerini azaltmaktadır (ERRC, 2012). Avrupa Birliği İlerleme Raporu'na (2012) göre, Türkiye'deki Roman vatandaşların çocuklarının okulu bırakma ve okula devamsızlık oranlarının ilkokullarda bile yüksek olduğu bildirilmiştir. Büyük oranda Roman vatandaşların çocuklarının gittiği okullarda çalışan öğretmenler sıklıkla değişmekte ve başka okullara atanmakta ve bu durum, eğitim kalitesini etkilemektedir. Olumsuz hayat koşullarının yanı sıra, okulun kural ve yaptırımları, kız öğrencilerin aileleri tarafindan okula gönderilmek istenmemesi, başarısızlık kaygısı, erkek öğrencilerin para kazanma isteği, Roman ailelerin okul tarafından kendilerine önyargılı yaklaşılması ve her türlü sorunun kendi çocuklarına atfedildiğini düşünmeleri (Diktaş, Deniz ve Balcıŏlu, 2016) Roman öğrencilerin okula devamını azaltmakta ve başarılarını olumsuz etkilemektedir.

Sosyo-ekonomik değişimlerle birlikte Roman ailelerin kendi sınırlı eğitim yaşantılarına rağmen çocuklarının eğitime ihtiyaçları olduğu konusundaki görüşlerinin arttığı ileri sürülmektedir (Bhopal, 2004). Nitekim ailelerin okula yönelik tutumlarında olumlu yönde gelişmeler olduğunu gösteren araştırma 
bulgularına rastlanmaktadır (Wilkin, Derrington ve Foster, 2009). Aileleri okul ve eğitim konusunda ikna ederek güven sağlamalarına neden olabilecek iki etmen öne sürülmektedir. Bunlardan ilki sosyal bağdır. Sosyal bağ çocuğunun okulunda kendisiyle benzer özelliklere sahip kişilerin bulunmasını ifade etmektedir. Diğeri ise, velilerle akşam yemekleri ve okul ziyaretleri, velilerle özel toplantılar yapılarak aile katılımının sağlanmasıdır (Wilkin ve ark., 2010). Ayrıca ailelerin okul tarafından iyi biçimde karşılanmaları okulu ziyaret etmelerini sağlayan önemli etmenler arasındadır. Konu ile ilgili yapılan araştırmalara göre katı olmayan eğitim programları uygulamaları, gerçekçi ve esnetilebilir okul politikaları, okulun aile katılımını sağlayarak ilişkilerini geliştirmesi, okulların tüm öğrencileri ve aileleri kapsayan bir eğitim sürecini gerçekleştirmelerini sağlayabilir (Cudworth, 2010). Hoover-Dempsey, Bassler ve Burow'a (1995) göre, ailelerin aile katılımına yönelik istekliliğini etkileyen bazı etmenler bulunmaktadır. Bunlar, ebeveynin rol yapısı, öz yeterlik algısı, okul yönetiminden algıladığı katılım daveti ve çocuğundan algıladığı katılım davetidir. Ailelerin farklı özelliklerini anlamaya çalışan okulların aile katılımı konusunda çeşitli seçenekler sunmaları katılımın etkililiğini sağlamakta ve öğrenci başarısını arttırmaktadır (Estyn, 2009; Lopez, 2001). Bu bağlamda Roman ailelerin değişen yaşam koşulları kapsamında eğitime bakış açılarının incelenerek aile katılımlarının sağlanabilmesi, eğitim öğretim sürecindeki okula devamsızlık, başarısızlık gibi sorunların önlenmesinde oldukça önemli görünmektedir. Bu anlamda, Roman ailelerin etkili olarak eğitime katılımlarının sağlanmasında okul yönetiminden, öğretmenden kısacası okuldan beklentilerinin neler olduğunun belirlenmesi kadar, Roman ailelerin eğitime 'nasıl' katılabileceklerinin bilinmesi otantik, kültüre uyumlu bir aile katılım anlayışının geliştirilebilmesi açısından önemli ve araştırmaya açı bir konudur. Dolayısıyla Roman ailelerin çocuklarının eğitim öğretim süreçlerine yönelik görüşleri ve aile katılımına yönelik beklentilerinin neler olduğu bu araştırmanın problemini oluşturmaktadır.

$\mathrm{Bu}$ araştırmada Roman ailelerin temel eğitim kapsamındaki çocuklarının eğitim süreçlerine nasıl katılabileceklerinin incelenmesi ve bu katılımın etkin olarak işletilebilmesi için okul yönetiminden, öğretmenlerden, velilerden ve diğer okul paydaşlarından beklentilerinin ortaya çıkarılması, otantik Roman kültürüne uyumlu, ortaklaşa bir aile katılım anlayışının geliştirilmesi amaçlanmıştır. Araştırmanın amacına dayalı olarak şu sorulara yanıt aranmıştır: 
1. Roman aileler çocuklarının eğitim öğretim süreçlerine 'nasıl' katılım göstermektedirler?

2. Roman ailelerin eğitime katılım gayretlerinin etkinleştirilmesinde okuldan beklentileri nelerdir?

3. Ailelerin, okulun katılıma ilişkin beklentilerini karşılamadaki zorlukları nelerdir?

\section{Yöntem}

\section{Araştırma Deseni}

$\mathrm{Bu}$ araştırma nitel araştırma deseninde tasarlanmıştır. Nitel araştırma, yaşantıların sosyal ve psikolojik yönlerine yönelik çeşitli stratejiler ve yöntemler sağlar (Camic, Yardley ve Rhodes, 2003). İnsan davranışı ancak esnek ve bütüncül bir yaklaşımla araştırılabilir ve bu yaklaşımda araştırmaya dahil olan bireylerin görüşleri ve deneyimleri büyük önem taşır (Yıldırım ve Şimşek, 2011). Dolayısıyla bireylerin yaşantılarına yönelik gerçekçi örneklerin ortaya çıkarılmasını desteklemektedir (Robson, 2011).

\section{Çalışma Grubu}

Araştırmada amaçlı örnekleme yöntemlerinden ölçüt örnekleme yöntemi kullanılmıştır. Araştırmanın örnekleminin belirlenmesinde katılımcıların okur yazar olan Roman velilerden oluşması ve çocuklarının temel eğitim kapsamında olması ölçüt olarak alınmıştır. Kocaeli ilinde Roman ailelerin yoğun olarak yaşadığı bölgeler ve bu bölgelerde çocukları temel eğitim alan çalışma, yaş ve eğitim durumları farklı olan velilerin görüşlerinin yansıtıldığı bir çalışma grubu oluşturulmuştur. Katılımcıların çalışma ve eğitim durumlarının çeşitliliği sağlanarak maksimum çeşitlilik örneklemesi kullanılmıştır. Böylelikle farklı eğitim seviyesinde ve çalışma koşullarında olan velilerin aile katılımına yönelik beklentileri ortaya koyulmaya çalışılmıştır.

Araştırmada maksimum çeşitliliği sağlamak açısından Kocaeli Roman Kadınlar Derneği'nin, Çalışma ve Sosyal Güvenlik Bakanlığı tarafından yürütülen Dezavantajlı Kişilerin Sosyal Entegrasyonu ile İstihdam Edilebilirliklerinin Geliştirilmesi Hibe Programı kapsamında başlatılan, "Roman Kadınların İkinci Baharı" projesi incelenmiştir. Projenin ana hedefi dezavantajlı grupları işgücü piyasasına dahil etmektir. Ayrıca Kadınların işgücü piyasasına aktif olarak dahil edilmesi ve çeşitli alanlarda kendilerini geliştirmeleri amaçlandığı görülmüştür. Dolayısıyla bu araştırmanın örneklemini 2016 -2017 Eğitim öğretim yılında "Roman Kadınların İkinci Baharı" projesine katılım gösteren farklı eğitim düzeyi ve yaşlarda olan, çocukalrı temel eğitime devam 
etmekte olan 13 kadın katılımcı oluşturmuştur.

Araştırma kapsamına alınan katılımcıların tamamı okur yazardır. Eğitim düzeyleri açısından beş katılımcı lise, altı katılımcı ortaokul ve iki katılımcı ilkokul mezunudur. Bununla birlikte sekiz katılımoı herhangi bir işyerinde çalışmamaktadır. Beş katılımcı ise düzenli olarak bir işyerinde çalışmaktadır. Katılımcıların yaşları 20 ile 55 arasında değişmektedir.

\section{Verilerin Toplanması}

Nitel desende tasarlanan bu araştırmanın amacına dayalı olarak "Roman Kadınların İkinci Baharı" projesine katılım gösteren ve okur yazar olup çocukları temel eğitim kapsamında olan velilerden ve proje yürütücülerinden görüşme yapmak için gerekli izinler alınmıştır. Katılımcıların proje kapsamında eğitim aldıkları günler belirlenip bu tarihlerden uygun olan birgün görüşme günü olarak belirtilmiştir.

Roman katılımcılardan elde edilen veriler odak grup görüşme tekniği ile toplanmıştır. Odak grup görüşmesi Kocaeli Roman Kadınlar Derneği çalışma ofisinde gerçekleştirilmiştir. Görüşmenin bu ofiste gerçekleştirilme nedeni Proje kapsamında katılımcıların eğitim için belirli günlerde bu ofise çağrılmalarıdır. Görüşmeye sadece kadın katılımcılar katılmış öğrenciler görüşme esnasında bulunmamışlardır. Görüşmede, görüşmecilerin düşüncelerini açılamalarında serbest olmaları, görüşmenin belirli bir süreyle sınırlı olmaması, anlaşılmayan soruların tekrar açıklanması sonucunda derinlemesine bilgi toplanması sağlanmıştır. Görüşmelerde belirli bir süre sınırı koyulmamıştır. Tek otrurumda gerçekleştirilen odak grup görüşmesi 110 dakika sürmüştür. Ayrıca görüşmelerde araştırmacı hem not alma hem de ses kayıt cihazı kullanma yöntemlerini bir arada kullanmıştır.

\section{Veri Toplama Aracı}

Araştırmada konu ile ilgili literatür incelendikten sonar çalışmanın genel amaçlarına uygun olarak yarı yapılandırılmış görüşme formu oluşturulmuştur. Araştırmacılar tarafından oluşturulan görüşme formu uygulama öncesinde iki alan uzmanının görüşüne sunularak soru yapılarında anlaşılırlığı sağlayacak değişikliklere gidilmiştir. Görüşme formuna son hâli verilerek odak grup görüşmelerinde 10 aç1k uçlu sorudan oluşan "Aile Katılımı Görüşme Formu" kullanılmıştır. Görüşme formunda katılımcıların çocuklarıyla okul arasında kurdukları iletişime, aile katılımını nasıl gerçekleştirdiklerine, bu süreçteki yaşantılarına ve bu yaşantılara sebep olan etmenlere yönelik sorular 
yer almıştır. Ayrıca aile katılımının etkili hâle getirilmesi için öneriler istenmiş ve bu öneriler de analize tabi tutulmuştur.

\section{Verilerin Analizi}

Elde edilen verilerin analizinde içerik analizi yöntemi kullanılmıştır. $\mathrm{Bu}$ süreçte verilerin kodlanması, kategorilerin bulunması, kodların ve kategorilerin düzenlenmesi, bulguların tanımlanması ve yorumlanması aşamaları takip edilmiştir. İçerik analizi elde edilen verilerin sistematik biçimde kodlanması ve kategorize edilmesi, birbirleri ile ilişkileri ve yapılarının ortaya koyulması sağlanır (Gbrich, 2007). Bu bağlamda içerik analizinin amacı sınıflandırmalarda katılımcıların söyeldikleri, söylemlerinin nedenleri ve etkilerinin betimlenmesidir (Bloor ve Wood, 2006).

\section{Bulgular}

Araştırmanın birinci alt probleminde "Roman aileler çocuklarının eğitim öğretim süreçlerine nasıl katılım göstermektedirler?” sorusu ele alınmıştır. Elde edilen verilerin analizinde saptanan kavramsal kategoriler ve içerdikleri kodlar Tablo 1'de sunulmuştur.

Elde edilen verilere göre velilerin çocukların eğitim öğretim süreçlerine katılma biçimleri okul temelli ve ev temelli kategorileri altında toplanmıştır. Velilerin okul temelli katılım biçimleri kategorisi altında belirttikleri kodlar "okula gitme, müdür, öğretmenle görüşme, telefon aracilığıyla öğretmenle görüşme, okul toplantılarına katılma, okul etkinliklerine katılma, okula giderek çocuğun arkadaşları ile görüşme" şeklindedir. Ev temelli katılım biçimleri ise, çocukla okul hakkında konuşma, çocuğu okul etkinliklerine katılmaya teşvik etme, aile büyüklerinin çocuğu takip etmesi, okul giderlerini karşılama, nasihat etme, ödüllendirme, ödev/etkinlik yapma, okula hazırlama, her istediğini yapma, çocukla okul hakkında konuşma.

Tablo 1. Velilerin Çocuklarının Eğitim Öğretim Süreçlerine Katılma Biçimleri

\begin{tabular}{ll}
\hline Kategori & Kod \\
\hline & Okula Gitme \\
& Müdürle Görüşme \\
& Öğretmenle Görüşme \\
Okul Temelli & Telefonla görüşme \\
& Toplantılara Katılma \\
& Okul Etkinliklerine Katılma \\
& Okulda Çocuğun Arkadaşları ile Konuşma \\
\hline
\end{tabular}




\begin{tabular}{ll}
\hline & Çocukla Okul Hakkında Konuşma \\
& Çocuğu Okul Etkinliklerine Katılmaya Teşvik Etme \\
& Aile Büyüklerinin Çocuğu Takip Etmesi \\
& Okul Giderlerini Karşıllama \\
& Nasihat Etme \\
Ödüllendirme \\
Ödev/Etkinlik Yapma \\
Okula Hazırlama \\
Her İstediğini Yapma \\
Çocukla Okul Hakkında Konuşma \\
\hline
\end{tabular}

Velilerin çocuklarının eğitim öğretim süreçlerine katılma biçimlerine ilişkin görüşleri Tablo 2'de verilmiştir.

Tablo 2. Velilerin Çocuklarının Eğitim Öğretim Süreçlerine Katılma Biçimlerine İlişkin Görüşleri

\begin{tabular}{|c|c|}
\hline teg & rüş \\
\hline \multirow{4}{*}{$\begin{array}{l}\text { Okul } \\
\text { Temelli }\end{array}$} & :... Okula gidip geliyordum. Çalışsam da devamlı okula uğruyordum. \\
\hline & $\begin{array}{l}\text { K13: ... Telefon açıyorlar, anlaşıyoruz. Bizi anlıyorlar. Çocuğun psikolo- } \\
\text { jisinden anlıyorlar. Gidip konuşmak lazım gidip konuşunca anlaşabiliyo- } \\
\text { ruz. }\end{array}$ \\
\hline & $\begin{array}{l}\text { K4: ... Her hafta yapılan etkinlikler oluyor, gidip malzemeleri alıyoruz } \\
\text { gönderiyoruz. Biz de katıllyoruz, gidiyoruz okula. }\end{array}$ \\
\hline & $\begin{array}{l}\text { K1: Benim oğlumun astım bronşiti vardı. Hasta olmasın yorulmasın ve } \\
\text { uykusunu da alsın okula giderken diye araba aldık arabayla okula götürür- } \\
\text { dük. Arabada } 5 \text { dakika daha fazla uyusun diye uyandırmazdım onu okula } \\
\text { gelinceye kadar. Okulda hasta olmasın tozdan diye hademelik yaptım. } \\
\text { Hergün snıfı temizledim, yerleri sildim, her işi yaptım havalandırdım. } \\
\text { Elimde bir torba çamaşırı üstünü değişirdim. Saat 3'e kadar temizlik ya- } \\
\text { pardım. }\end{array}$ \\
\hline
\end{tabular}

K7: Kızıma soruyorum evde "Ne yaptın bugün, ne ögrendin, okulda arkadaşlarınla aran nasıldı?" diye. Sürekli çıkmıyorum ama arkadaşlarıyla problem yaşamışsa çıkıyorum okula, nedenini öğreniyorum. Benim kızım sorun çıkarmaz bazen arkadaşlarıyla sorun olabiliyor nedenini öğrenmek

Ev istiyorum. Öğretmenle konuşuyorum bazen arkadaşlarıyla da konuşuyoTemelli rum.

K10: Alıyorum defteri kalemi onunla boyama yapıyorum. Etkinlik yapıyorum.

K8: Ben çocukların her şeylerini hazırlıyorum işe gitmeden önce. Kahvaltılarını hazırlıyorum, kıyafetlerini, paralarını koyuyorum. Soruyorum akşam gelince bugün neler yaptınız diye.

K2: Aile büyüklerimiz destek oluyor. Ben çalışıyorum mesela annem takip ediyor çocukları. Okula gidip gelmesini.

K3. Çocuğumun katılması için maddî manevî her türlü desteği sağlamaya 
çalışıyoruz. Okul etkinliklerine de katılması için destekliyoruz.

K12: Ödevlerine yardım ediyorum. Soruyorum, neler yaptın okulda diye.

K2: Konuşurum kızımla. "Kızım bak önünde biz örnek varız. Ben 20 yaşında evlendim. Eşimle anlaşamadık, kavgamız gürültümüz hep olurdu. Her zaman oku derim ona, erken evlenme, erken yaşta evlilik kurma, çalış çabala, iş sahibi ol, kendi ayaklarının üstünde dur. Eşinin parasına muhtaç kalma ileride eşinden ayrılsan bile kendi paran olur, çocuklarıma kendim bakabilirim dersin." derim. Akıl veriyorum hep.

K6: Ben ödül koyuyorum. Eğer dersini yaparsan, derslerinde başarılı olursan sana şunu alacam diyorum. Öğretmen önerdi bunu. Yararlı da oldu. Böyle destek oldum.

K3: Elimizden geldiği kadar her şeyi yapıyoruz. Çocuğun her istediğini yapıyoruz. Paramız olmasa bile çocuk bir şey istediğinde üzülmesin diye yapıyor mutlu ediyoruz.

K3: Ben mesela her yağmur yağdığında çocuklarımı hiç okula yollamam. Hasta olacak diye yollamıyorum. Islanıp eve gelecekler diye korkuyorum. Üşütür diye.

K10: Geç kaldın diyorum ama gitmek istemiyor, küçüklükten alıştı. Kıyamiyorum ben de.

K4: ... Yalnız şımartıyoruz çocukları her istediklerini alıyoruz, yapıyoruz hep. Karnı ağrıyorsa yollamıyoruz okula.

K9: Aslında çocuğu biz etkiliyoruz, kar yağsın yağmur yağsın göndermiyoruz biz de. Benim kızım yaşıtlarından iriydi. Dalga geçerlerdi okulda. Müdürle bile konuştum ama istemedi okumak. Kızımı ağlar görünce dayanamadım. Dışarıdan bitirmeye çalışıyor şimdi pişman okumadığı için.

Velilerin ifadeleri incelendiğinde çocukların eğitim öğretim süreçlerine çoğunlukla ev temelli katılım gösterdikleri görülmüştür. Ev temelli katılım kategorisinde çocukla okul hakkında konuşma, nasihat etme ve her istediğini yapma kodlarının katılımcılar tarafından sıklıkla dile getirildiği görülmüştür. Velilerin ev temelli katılım sürecinde çocuklarıyla okul hakkında konuşurken ve nasihat ederken, okula gitmelerini, eğitim almadıkları kendilerine benzeyeceği ve hayatta başarısız olacağına yönelik ifadeler kullandıkları görülmüştür. Birçok veli çocuklarının gerek okul ihtiyaçları gerekse başka konulardaki isteklerini her zaman yerine getirmeye çalışarak çocuklarını desteklediklerini belirtmiştir. Örneğin çocukların okula gitmek istemedikleri zamanlarda onları zorlamadıklarını belirten ifadeleri çoğunluktadır. Veliler, hava koşulları, uykuyu alamama, hasta olma, üşenme, kendini dışlanmış hissetme, okula, öğretmene ve arkadaşlara yönelik olumsuz duygulara sahip olma gibi durumlarda çocuklarının okula gitmeme yönündeki isteklerini hoşgördüklerini belirtmişlerdir. 
Araştırmanın ikinci alt probleminde "Ailelerin, okulun katılıma ilişkin beklentilerini karşılamadaki zorlukları nelerdir?” sorusu ele alınmıştır. Elde edilen verilerin analizinde saptanan kavramsal kategoriler ve içerdikleri kodlar Tablo 3 'te sunulmuştur.

Tablo 3. Velilerin Okulun Katılıma İlişkin Beklentilerini Karşılama Konusunda Yaşadıkları Zorluklar

\begin{tabular}{ll}
\hline Kategori & Kod \\
\hline \multirow{3}{*}{ Ayrımcılık } & Öğretmenin ayrımcı davranışları \\
& Müdürün ayrımcı davranışları \\
& Velilerin ayrımcı davranışları \\
& Öğrencilerin ayrımcı davranışları \\
\hline \multirow{3}{*}{ Okul Masrafları } & Okul ihtiyaçları \\
& Özel gün kutlamaları/partileri \\
& Okul etkinliklerine yönelik masraflar \\
\hline
\end{tabular}

Elde edilen verilere göre velilerin okulun katılıma ilişkin beklentilerini karşılamadaki zorlukları "Ayrımcılık" ve "Okul masrafları" kategorileri altında toplanmıştır. Ayrımcılık kategorisi altında saptanan kodlar, öğretmen tarafından gösterilen ayrımcı davranışlar, müdürün ayrımcı davranışları, velileri ayrımcı davranışları, öğrencilerin birbirlerine yönelik ayrımcı davranışları şeklindedir. Okul masrafları kategorisi altında belirtilen kodlar ise, Okul ihtiyaçları, özel gün kutlamaları/partiler ve okulda düzenlenen etkinliklerden kaynaklanan masraflar şeklindedir. Tablo 4'te velilerin okulun katılıma ilişkin beklentilerini karşılama konusunda yaşadıkları zorluklara ilişkin görüşleri verilmiştir.

Tablo 4. Velilerin Aile Katılımı Konusunda Yaşadıkları Zorluklara İlişkin Görüşleri

\begin{tabular}{ll}
\hline Kategori & Görüş̧ \\
\hline & K4: Çocuğum okula gitmemişse nasılsa annesi göndermiyordur diye \\
& aramıyorlar. Biz ilgisiz anne babalar değiliz. \\
& K6: Meğer okula gitmiyorlarmış. Komşular görüyormuş dışarıda. \\
& Çok şaşırdık. Öğretmen hiç haber vermedi. Bir çocuk da okulu sev- \\
& medi mi sevmiyor isste. Eşim şikayet etti okula biz yolluyoruz, gitmi- \\
Ayrımcılık & $\begin{array}{l}\text { yor çocuklar diye. Aramadılar tanıdıklardan öğrendik okula gitme- } \\
\text { diklerini. }\end{array}$ \\
& K5: Toplantılara gidiyoruz. Asıl sorun ayrımcıllk burada. Ayrımcı- \\
& lığı sınıftaki veliler de yapiyor. Onların çocuklarıyla konuşmayın, \\
& yan yana oturmayın diyorlar çocuklarına. Toplantılarda bile ayrı otu- \\
& ruyoruz, veliler yüzünden gruplaşma oluyor. Bu bizi rahatsız ediyor \\
& tabii. Ben bir veliyle tartıştım bu yüzden yanımızdan kalktılar diye.
\end{tabular}


Gittim siz dedim insan ayırıyorsunuz biz Romanız diye. Biz de insanız biz de bu aynı devletin insanlarıyız. Bizim ne farkımız var sizlerden. Sizin evinizde olmayan şeyler belki bizim evimizde var. Bizi küçük göremezsiniz, insanları ayıramazsınız dedim. Sonra benden özür diledi. Bu yüzden veli toplantılarına gitmek istemiyoruz. Soğuduk bu tür şeyler yüzünden.

K12: Bazı çocuklar okulda dişlandığı için okuldan kaçıyorlar. Hem çocuklar hem öğretmenleri dişladı. "Siz o mahallenin çocuğusunuz." diyorlar, Roman okulundan gelmişsiniz diyorlar. Aralarına kabul etmiyorlar. Okuldaki arkadaşları çok etkiledi.

K7: Benim kızım içine kapanıktı. Sessizdi. Ayrımcılık yapıldığı için daha da isteksiz oldu, gitmek istemedi okula, tercih etmedi. Okul müdürüyle de gittik konuştuk. $\mathrm{O}$ da dedi utangaç bir çocuk diye. Okumak istemiyor dedi.

K4: Mesela çocuk okula gitmeyince "Hasta oldu." diyorum. İnanmıyorlar. "Düğünde mi kaldı?" diye cevap veriyorlar bana. Aşağılanıyoruz, bunu sadece okul değil toplum da yapıyor. Ben en çok öğretmenlerden gördüm. Bir öğretmenin böyle söylemesini ben kaldıramam. Başka bir veliye söylemiyorlar böyle de neden ben gelince ya da benim çocuğum okula gelemeyince bana böyle cevap veriyorlar. İşte bu ayrımcılıktır bence.

K4: Okuldan para istiyorlar, hikaye kitabı istiyorlar alıyoruz, her hafta yapılan etkinlikler oluyor, gidip malzemeleri alıyoruz gönderiyoruz. Biz de katılıyoruz, gidiyoruz okula. Çok zor çocuk okutmak. Bir çocuk olsa altından kalkarsınız ama iki ya da daha fazla olunca okul masrafları da artıyor.

K8: Biz okula kaydettirmeye çalışırken bizi caydırmaya çalıştılar. Para istediler, ben veremem dedim. Müdürle çok tartıştık bu yüzden. Para vermezseniz okuyamaz dediler. Vazgeçin zaten okumaz bu dediler. Ben de boya aldım okula öyle devam etti çocuğum.

Okul K10: Maddî manevî yardım eden okullar oluyor. Bazı okullar duruMasrafları mun yoksa yardım ediyorlar. Bazen yetişebildiğimiz durumlar oluyor ama yetişemediğim konularda yardımcı oluyorlar.

K11: Yetişemediğimiz karşılayamadığımız şeyler oluyor. Bunları veliler de yapıyor mesela olmayacak şeyler çıkarıyorlar. Doğum günü partileri düzenliyorlar. Katılmamız zor bizim ücretli oluyor bu yerler.

K12: Okul gösterileri benim bildiğim hep okulda yapılırdı. Ne gerek var şimdi salon tutuyorlar bu gösteriler için. Salon da ücretli oluyor. İsterim katılmayı gitmeyi ama yapamıyorum. Öğretmenlere sorduğumuzda bunu velilerin istediğini söylüyorlar. Böyle şeyler çıkarmasalar daha iyi olur. 
Araştırma bulgularına göre, velilerin okula katılım konusundaki girişimleri çoğunlukla ayrımcı davranışlar nedeniyle engellenmektedir. Öğretmen, okul müdürü ve zaman zaman öğrencilerin roman öğrencilere yönelik söylemleri veliler ve çocukları tarafindan rahatsız edici bulunmakta ve bu durum çocukların okula yönelik olumsuz duygulara sahip olmasına neden olabilmektedir. Bu tür durumlarda veliler çocuklarının okula gitmeme isteklerini haklı görmektedirler. Ayrıca Roman ailelerin, diğer velilerin ayrımcı tutum ve söylemleri nedeniyle toplantılara katılmak istemediklerini, öğretmenlerin ve müdürlerin Roman ailelerin çocuklarının başarısız olduğuna, okula devam etmek istemediğine yönelik olumsuz görüşlerinin ise aslında gerçekçi olmad1ğını eğitime önem verdiklerini, çocuklarının okumasını istediklerini belirttikleri görülmüştür. Bununla birlikte bazı velilerin çocuklarının eğitim öğretim süreçlerine her türlü destek vermek isteseler de çocukların okuma isteğinin içten gelen bir duygu olduğuna yönelik ifadeleri bulunmaktadır. Ayrıca erkek çocuklarının okuma konusunda daha az istekli olduğu dile getirilmiştir. Velilerin bu konudaki ifadelerinden bazıları şu şekildedir; "Benim üç çocuğumdan ikisi okudu, küçük erkek okumadl. İstemedi. IÇinde yoktu çocuğun. Bazı çocugun içinde olur okur, bazısı ne yapsan okumaz." (K13). "Erkek çocuklar istemiyor gitmek. Benim de kiz okudu ama erkek okumadı terk etti. Ne yapsam gönderemedim." (K12). "Benimkiler okudu ama çevreden biliyoruz, siz ne yaparsanız yapın çocuğun içinde varsa okumak o okuyor o zaman, ister para ver, ister okula git takip et, ister döv bağır ya da güzellikle konuş, okumak istemiyorsa okumuyorlar. İçinde olmayan çocuk okumuyor." (K1).

Araştırmanın üçüncü alt probleminde "Roman ailelerin eğitime katılım gayretlerinin etkinleştirilmesinde okuldan beklentileri nelerdir?" sorusu ele alınmıştır. Elde edilen verilerin analizinde okuldan beklentiler kategorisi altında saptanan kodlar Tablo 5'te sunulmuştur.

Tablo 5. Velilerin Eğitime Katılım Gayretlerinin Etkinleştirilmesinde Okuldan Beklentileri

\begin{tabular}{ll}
\hline Kategori & Kod \\
\hline & Maddî yardım \\
Okuldan Beklentiler & Haberdar edilme \\
& İlgi ve destek \\
& Farklı arkadaş çevresi \\
& Proje \\
\hline
\end{tabular}

Elde edilen verilere göre velilerin okulun katılıma ilişkin beklentileri "okuldan beklentiler" kategorisi altında toplanmıştır. Bu kategori altında 
saptanan kodlar, maddî yardım, haberdar edilme, ilgi ve destek, farklı arkadaş çevresi ve proje şeklindedir. Velilerin bu konudaki sorulara ilişkin görüşlerinin genel olarak ilgi ve destek kodu ile proje kodunda yoğunlaştığı görülmüştür. Veliler, okula katılımlarının desteklenmesi için kendilerine inanılmasını beklemekte, maddi durumlarının gözetilmesi, onlarla ilgilenilmesi ve çocuklarla ilgili haberdar edilmelerini istemektedirler. Ayrıca okulların bu konularla ilgili geliştirecekleri projelerin olmasının çocuklarının okula gitmelerinde, eğitim hayatlarına devam etmelerinde ayrıca farklı arkadaş çevresine sahip olmalarında etkili olacağını düşünmektedirler. Velileri bu konudaki görüşlerinden bazıları şu şekildedir; "Maddî bakımdan yardım eden okullar oluyor. Bazı okullar durumun yoksa yardım ediyorlar. Bazen yetişebildiğimiz durumlar oluyor ama yetişemediğim konularda yardımcı olmalılar." (K10), “Öğretmenler daha ilgili olmall, çocukları ayırmamall. Her okul haber vermiyor. Aramıyor çocuk okula gitmeyince. Gelmezse gelmesin diyor. Aman boşver zaten onun çocuğu okumuyor, gelse ne olur gelmese ne olur diyor." (K3), "Bizim çocuklar da dik biraz. İkna edilmeli, sevdirmeliler öğretmenleri." (K1), "Okullar çocuklara okulu sevdirmeli, okumayl sevdirmeli, takip etmeliler." (K3), "Okullar haber vermeli bize, okula gidiyor mu? Bize bilgi vermeliler." (K7), "Benim küçük oğlum sadece kendi mahalle arkadaşlarını seviyordu. Dlşarıdan başka arkadaşı yoktu. Okula da gitmek istemedi ikisi de. Okulların projeleri olursa çevresi değişir çocukların." (K6).

\section{Sonuç}

Araştırmada Roman velilerin aile katılımını ev temelli ve okul temelli olarak gösterdikleri sonucuna ulaşılmış; ev temelli katılımın nasihat etme, çocukla okul hakkında konuşma ve her istediğini yapma şeklinde yapıldığı görülmüştür. Velilerin çocuklarının her istediğini yaparak onları desteklemesi Roman ailelere özgü bir durum olarak değerlendirilebilir. Nitekim Roman ailelerinin çocuklarına yönelik daha korumacı tutum içinde bulundukları bazı araştırma bulgularında da belirtilmiştir (McCray, 2006).

Roman velilerin okula katılım konusunda yaşadıkları en önemli zorluk "ayrımcılık" olarak nitelendirilmiştir. Roman velileri kendilerinin ve çocuklarının okul müdürü, öğretmen, veli ve diğer öğrencileri tarafindan Roman oldukları için etiketlendiklerini ifade etmişlerdir. Bu durum Roman çocuklarının okulu terk etme ve devamsızlık yapmalarına neden olabilmektedir. Velilerin okul katılımını engelleyen bir diğer neden ise okul masraflarını karşılamadaki güçlüklerdir. Araştırmada elde edilen bu sonuçlar Romanlarla ilgili yapılan 
sınırlı sayıdaki araştırma sonuçlarıyla örtüşmektedir (Diktaş, Deniz ve Balcıoğlu, 2016; Genç, Taylan ve Barış, 2015; Kabakl1, 2013).

Araştırmada çocukların eğitim öğretim süreçlerine sadece anne babaların ve bazı aile büyüklerinin destekleyici olduğu belirtilmiştir. Özellikle erkek çocukların kendi çevrelerindeki diğer çocukları örnek alarak okulu terk ettikleri görülmüştür. Bu durum çocukların eğitim konusunda isteksiz olmalarına sebep olabilmektedir (Diktaş, Deniz ve Balcıŏlu, 2016; Kabakl1, 2013).

Araştırmada velilerin çocukların her istediğini yapma ve ayrımcı davranışlardan koruma amacıyla çocuklarının okula gitmeme isteklerini doğal karşıladıkları saptanmıştır. Araştırmanın çalışma grubundaki velilerin çocukların eğitim öğretim süreçlerine önem verdiklerini ifade etmelerine rağmen bu süreçte okuldan ve öğretmenlerden ilgi, destek ve anlayış bekledikleri böylece okula katılım konusunda daha istekli olabilecekleri sonucuna ulaşılmışıtır. Araştırmanın bu sonucu velilerin hayata dair beklentilerinin olduğunu göstermektedir. Bugüne kadar yapılan bazı araştırmalardan (Uzun ve Bütün, 2015) farklı olarak velilerin kendileri ve çocukları için belirlediği hedeflere eğitimle ulaşabileceklerine yönelik inançları olduğu görülmüştür. Ayrıca veliler okullardan çocuklarının bulundukları sosyal ortamdan farklı ortamlarda bulunmalarını sağlayacak projeler geliştirmelerini de beklemektedirler (Kabaklı, 2013). Bu projelerin kendilerini ve çocuklarını okula katılıma teşvik edeceğini belirtmektedirler. Nitekim alt kültürlerin çeşitli özelliklerini anlamaya çalışan okulların aile katılımı konusunda farklı seçenekler sunmaları katılımı arttırabilmektedir (Estyn, 2009; Lopez, 2001). Roman aileler ile okul arasında güçlü bağların oluşturulmasına yönelik çalışmalar bu amaca katkı sağlayabilir. Okul çalışanlarının Roman ailelerin özellikleri, Roman kültürü konusunda bilgili olmaları amacıyla yazılı ve görsel dokumanlarla desteklenmeleri, Roman ailelerin kendi çocuklarını okula devam ve eğitim öğretim konularında destekleyebilmeleri amacıyla okur yazarlık eğitimi destekleri verilmesi, Roman öğrenciler, aileleri ve yaşanan sorunlarla ilgili okul yönetimine ve öğretmenlere kolayca ulaşılabilirliğin sağlanması, Roman öğrencilerin okul gezilerine ve çeşitli kulüp etkinliklerine katılımları konusunda desteklenmeleri etkili çalışmalar olarak önerilebilir (Gould, 2017).

Araştırma sonuçlarından yola çıkılarak Roman ailelerin aile katılımının teşvik edilmesi amacıyla okullar tarafından veli ve öğrencilerin bütünleştirildiği çeşitli sanatsal, kültürel ve sportif etkinlikler düzenlenebilir. Bu yolla ayrımcılığa yönelik tutumların azalması beklenebilir. Ayrıca okulların ve 
ailelerin birbirlerinden beklentilerine yönelik konuşmaların gerçekleşeceği platformların oluşturulması, ailelerin kendilerine özgü yapılarının okul yönetimi ve öğretmenler tarafindan tanınmasına olanak sağlayabilir. Okulun amaçlarının açık biçimde velilerle paylaşılarak bu amaçların gerçekleştirilmesinde velilerin rollerinin belirlenmesi ve bu süreçte velilerin olası desteğinin nasıl sağlanabileceğine yönelik görüşlerin paylaşılması önerilebilir. Konuyla ilgili yapılacak diğer araştırmalarda farklı alt kültürlerin aile katılım formlarının ortaya koyulması gözönünde bulundurabilir.

\section{Kaynakça}

Abbak, B. S. (2008). Okul öncesi eğitim programındaki aile katılımı etkinliklerinin anasınıfi ögretmenleri ve veli görüşleri açısından incelenmesi. Yayınlanmamış yüksek lisans tezi, Çukurova Üniversitesi Sosyal Bilimler Enstitüsü.

Akkan, B. E., Deniz, M. B. ve Ertan, M. (2011). Sosyal dışlanmanın Roman halleri. İstanbul: Punto Bask1.

Avrupa Komisyonu, (2012). Türkiye 2012 yıl ilerleme raporu (Yayın No. 336).

https://www.ab.gov.tr/files/AB_Iliskileri/AdaylikSureci/IlerlemeRaporlari/2012_ilerleme_raporu_tr.pdf

Bhopal, K. (2004). Gypsy travellers and education: Changing needs and changing perceptions. British Journal of Educational Studies, 52(1), 47-64.

Bloor, M. ve Wood, F. (2006). Keywords in qualitative methods: A vocabulary of research concepts. Thousand Oak, CA: Sage Publication.

Brotman, L. M., Calzada, E., Huang, K. Y., Kingston, S., Dawson-McClure, S., Kamboukos, D. ve Petkova, E. (2011). Promoting effective parenting practices and preventing child behavior problems in school among ethnically diverse families from underserved, urban communities. Child Development, 82(1), 258-276.

Camic, P., Yardley, L. ve Rhodes, J. E. (Ed.). (2003). Qualitative research in psychology: Expanding perspectives in methodology and design. Washington, DC: APA Publications.

Cudworth, D. (2010). Book review: Insiders, outsiders and ethers: Gypsies and Identity. Great Britain: University of Hertfordshire Press. 
Çağdaş, A., Özel, E. ve Konca, A. S. (2016). İlkokul başlangıcında velilerin aile kat1lım düzeylerinin incelenmesi. Eğitimde Kuram ve Uygulama, 12(4), 891-908.

Çakmak, Ö. Ç. (2010). Okul öncesi eğitim kurumlarında aile katılımı. Abant İzzet Baysal Üniversitesi Sosyal Bilimler Enstitüsü Dergisi, 20(20), 118.

Çalık, C. (2007). Okul çevre ilişkisinin okul geliştirmedeki rolü: kavramsal bir çözümleme. Gazi Üniversitesi Gazi Eğitim Fakültesi Dergisi, 27(3), 123-139.

Çınkır, Ş. ve Nayır, F. (2017). Okul aile işbirliği standartlarına ilişkin veli görüşlerinin incelenmesi examining parent opinions about school-parents cooperation standards. H. U. Journal of Education, 32(1), 245-264.

Doi: 10.16986/HUJE.2016015709

Dearing, E., Kreider, H., Simpkins, S. ve Weiss, H. B. (2006). Family involvement in school and low-income children's literacy: Longitudinal associations between and within families. Journal of Educational Psychology, 98(4), 653-664.

Derrington, C. ve Kendall, S. (2003). The experiences and perceptions of Gypsy Traveller pupils in English secondary schools. Encouraging voices. Dublin: National Disability Authority.

Derrington, C. (2005). Perceptions of behaviour and patterns of exclusion: Gypsy Traveller students in English secondary schools. Journal of Research in Special Educational Needs, 5(2), 55-61.

Diktaş, A., Deniz, A. Ç. ve Balcıŏlu, M. (2016). Uşak'ta yaşayan Romanların Türk eğitim sistemi içerisinde yaşadıkları problemler. Itobiad: Journal of the Human and Social Science Researches, 5(4), 1121-1142.

Durmuş, E. (2016). Ortaöğretim kurumlarında öğretmenlerin aile katılımıyla ilgili görüşlerinin incelenmesi: İstanbul-Sultanbeyli örneği. Yayınlanmamış yüksek lisans tezi, İstanbul Aydın Üniversitesi Sosyal Bilimler Enstitüsü.

Erdoğan, Ç. ve Demirkasımoğlu, N. (2010). Ailelerin eğitim sürecine katıl1mına ilişkin öğretmen ve yönetici görüşleri. Kuram ve Uygulamada Egitim Yönetimi Dergisi, 16(3), 399-431. 
ERRC-Avrupa Roman Hakları Merkezi (2012). Türkiye ülke profili 20112012.

http://www.errc.org/uploads/upload_en/file/turkey-country-profile2011-2012-in-turkish.pdf

Estyn (2009). Local authority support for the education of migrant workers. Cardiff: Estyn Publications.

Forray, K. R. (2003). Results and problems in the education of the Gypsy community. European Education, 34(4), 70-90.

Gbrich, C. (2007). Qualitative data analysis: an introduction (1. bask1). London: Sage Publications.

Genç, Y., Taylan, H. H. ve Barış, İ. (2015). Roman çocuklarının eğitim süreci ve akademik başarılarında sosyal dışlanma algısının rolü. The Journal of Academic Social Science Studies, 33, 79-97.

Gould, S. (2017). Promoting the social inclusion and academic progress of Gypsy, Roma and Traveller children: a secondary school case study. Educational Psychology in Practice, 33(2), 126-148.

Grolnick, W. S., Friendly, R. W. ve Bellas, V. M. (2009). Parenting and children's motivation at school. Handbook of motivation at school, 279-300.

Hayakawa, M., Englund, M. M., Warner-Richter, M. N. ve Reynolds, A. J. (2013). The longitudinal process of early parent involvement on student achievement: A path analysis. NHSA Dialog, 16(1), 103-126.

Hoover-Dempsey, K. V., Bassler, O. C. ve Burow, R. (1995). Parents' reported involvement in students' homework: Strategies and practices. Elementary School Journal, 95, 435-450.

Hoover-Dempsey, K. V., Walker, J. M., Sandler, H. M., Whetsel, D., Green, C. L., Wilkins, A. S. ve Closson, K. (2005). Why do parents become involved? Research findings and implications. The Elementary School Journal, 106(2), 105-130.

Jeynes, W. H. (2007). The relationship between parental involvement and urban secondary school student academic achievement: A meta-analysis. Urban Education, 42(1), 82-110.

Kabaklı, N. (2013). Barbaros ve Yeni Sahra Roman çocuklarının okullaşma 
süreci: Ebeveyn görüşleri. Yayınlanmamış yüksek lisans tezi, Yeditepe Üniversitesi Sosyal Bilimler Enstitüsü.

Kaplan, D. S., Liu, X. ve Kaplan, H. B. (2001). Influence of parents' selffeelings and expectations on children's academic performance. The Journal of Educational Research, 94(6), 360-370.

Keçeli-Kayısıl1, B. (2008). Akademik başarının artırılmasında aile katılımı. Ankara Üniversitesi Egitim Bilimleri Fakültesi, Özel Eğitim Dergisi, 9(1), 69-83.

Kılıç, D. (2009). Yenilenen ilköğretim programlarında ailenin eğitim fonksiyonunun öğretmen ve veli görüşlerine göre incelenmesi. Atatürk Üniversitesi Sosyal Bilimler Enstitüsü Dergisi, 13(1), 177-190.

Kıranşal. N. (2007). Illköğretim okullarında okul ve aile arasındaki etkileşim hangi düzeyde gerçekleşmektedir (Kars il örneği). Yayınlanmamış yüksek lisans tezi, Kafkas Üniversitesi Sosyal Bilimler Enstitüsü.

Kolukırık, S. (2008) Türkiye'de Rom, Dom ve Lom gruplarının görünümü. Hacettepe Üniversitesi Türkiyat Araştırmaları Dergisi, 5(8), 145-154.

Kotaman, H. (2008). Türk ana babalarının çocuklarının eğitim öğretimlerine katılım düzeyleri. Uludağ Üniversitesi Eğitim Fakültesi Dergisi, 21(1), 135-149.

Lee, J. S. ve Bowen, N. K. (2006). Parent involvement, cultural capital, and the achievement gap among elementary school children. American Educational Research Journal, 43(2), 193-218.

Liegeois, J. P. (1998). School provision for ethnic minorities: The Gypsy paradigm. Hatfield: University of Hertfordshire Press.

Lloyd, G. ve Stead, J. (2001). The boys and girls not calling me names and the teachers to believe me. Name calling and the experiences of travellers in school. Children and Society, 15(5), 361-374.

Lopez, G. (2001). The value of hard work: Lessons on parent involvement from an (im) migrant household. Harvard Educational Review, 71(3), 416-438.

McCray, E. D. (2006). The persisting issue of truancy. Intervention in School and Clinic. 42(1), 30-33. 
McKay, M. M. ve Stone, S. (2000). Influences on urban parent involvement: Evidence from the National Education Longitudinal Study. School Social Work Journal, 25(1), 16-30.

Myers, M. ve Bhopal, K. (2009). Gypsy, Roma and Traveller children in schools: understandings of community and safety. British Journal of Educational Studies, 57(4), 417-434.

Myers, M., McGhee, D. ve Bhopal, K. (2010). At the crossroads: Gypsy and Traveller parents' perceptions of education, protection and social change. Race Ethnicity and Education, 13(4), 533-548.

Ocaklı, I. (2013). AB Ülkeleri Roman Politikaları. http://investinedirne.org.tr/uploads/docs/06112013Sk8vI7.pdf

Özgan, H. ve Aydın, Z. (2010, Mayıs). Okul-aile işbirliğine ilişkin yönetici, öğretmen ve veli görüşleri. 9. Ulusal sinı öğretmenliği eğitimi sempozyити içinde. Fırat Üniversitesi’nde yapılan sempozyum, Elazığ.

Reynolds, M., McCartan, D. ve Knipe, D. (2003). Traveller culture and lifestyle as factors influencing children's integration into mainstream secondary schools in West Belfast. International Journal of Inclusive Education, 7(4), 403-414.

Robson, C. (2011). Real world research (3. bask1). Chichester, UK: Wiley.

Saban, A. İ. ve Şeker, M. (2010). İlköğretim 5. sınıf öğrencilerinin performans görevlerindeki başarıları ile ailelerinin eğitim öğretim çalışmalarına katılım düzeyleri arasındaki ilişkinin belirlenmesi. Çukurova Üniversitesi Sosyal Bilimler Enstitüsü Dergisi, 19(3), 361-390.

Salıc1-Ahioğlu, Ş. (2006). Öğretmen ve veli görüşlerine göre farklı sosyoekonomik düzeydeki ailelerin ilköğretim birinci sını ögrencilerinin okuma yazma sürecini etkileme biçiminin değerlendirilmesi. Yayınlanmamış yüksek lisans tezi. Çukurova Üniversitesi Sosyal Bilimler Enstitüsü.

Salinas, J. (2007). Reflections on educational policies for Spanish Gypsies. European Education, 39(1), 32-49.

Stewart, E. B. (2008). School structural characteristics, student effort, peer associations, and parental involvement: The influence of school-and individual-level factors on academic achievement. Education and Urban Society, 40(2), 179-204. 
Topçu, İ. (2013). Okulu geliştirmede velilerin rolü: Sivas il merkezinde bir durum çalışması. Yayınlanmamış doktora tezi, İnönü Üniversitesi Eğitim Bilimleri Enstitüsü.

Uzun, E. ve Bütün, E. (2015). Roman çocukların okula devamsızlık nedenleri ve bu durumun çocuklar üzerindeki etkileri. Hacettepe Üniversitesi Sağllk Bilimleri Fakültesi Dergisi, 2(1), 315-328.

Ünüvar, P. (2010). Aile katılımı çalışmalarına yönelik ebeveyn ve öğretmen görüşlerinin karşılaştırılması. Kastamonu Eğitim Dergisi, 18(3), 719730 .

Vural, D. E. ve Kocabaş, A. (2016). Okul öncesi eğitim ve aile katılımı. Elektronik Sosyal Bilimler Dergisi, 15(59), 1174-1185.

Waanders, C., Mendez, J. L. ve Downer, J. T. (2007). Parent characteristics, economic stress and neighborhood context as predictors of parent involvement in preschool children's education. Journal of School Psychology, 45(6), 619-636.

Warrington, C. (2007). Children's voices, changing futures: The views and experiences of young Gypsies and Travellers. Ipswich, UK: Ormiston.

Wilkin, A., Derrington, C. ve Foster, B. (2009). Improving the outcomes for Gypsy, Roma and Traveller pupils: literature review. http://dera.ioe.ac.uk/11361/1/DCSF-RR077.pdf

Wilkin, A., Derrington, C., White, R., Martin, K., Foster, B., Kinder, K. ve Rutt, S. (2010). Improving the outcomes for Gypsy, Roma and Traveller pupils. http://dera.ioe.ac.uk/11566/1/DFE-RR043.pdf

Yıldırım, A. ve Şimşek, H. (2011). Sosyal bilimlerde nitel araştırma yöntemleri (8. bask1). Ankara: Seçkin Yayıncılık. 